Article

\title{
Effect of Silica, Activated Carbon, and Alumina Supports on NiMo Catalysts for Residue Upgrading
}

\author{
Kirtika Kohli ${ }^{1,2, *} \mathbb{C}$, Ravindra Prajapati ${ }^{1}$, , Samir K. Maity ${ }^{1, *}$ and Brajendra Kumar Sharma ${ }^{2} \mathbb{C}$ \\ 1 Distillate and Heavy Oil Processing Division, CSIR-Indian Institute of Petroleum, Dehradun 248005, India; \\ ravimprajapati@gmail.com \\ 2 Prairie Research Institute-Illinois Sustainable Technology Center, University of Illinois Urbana-Champaign, \\ Champaign, IL 61820, USA; bksharma@illinois.edu \\ * $\quad$ Correspondence: kirtika@illinois.edu (K.K.); skmaity@iip.res.in (S.K.M.)
}

Received: 17 July 2020; Accepted: 17 September 2020; Published: 22 September 2020

\begin{abstract}
The effect of different supports such as silica (SBA-15), activated carbon (AC), and mesoporous alumina $\left(\mathrm{Al}_{2} \mathrm{O}_{3}\right)$ on catalytic activities of hydrotreating nickel molybdenum (NiMo) catalysts was demonstrated for upgrading vacuum residue. Nitrogen adsorption-desorption analysis showed that SBA-15 and the AC-supported NiMo catalyst possessed a very high surface area compared to the alumina-supported catalyst. However, $\mathrm{NiMo} / \mathrm{Al}_{2} \mathrm{O}_{3}$ catalyst possesses a higher pore diameter and pore volume with an appropriate surface area. X-ray diffraction (XRD) analysis showed that active metals were dispersed in the catalytic supports. Transmission electron microscopy (TEM) analysis revealed the presence of type II active $\mathrm{MoS}_{2}$ sites in the $\mathrm{NiMo} / \mathrm{Al}_{2} \mathrm{O}_{3}$ catalyst, which showed weak metal-support interactions having a high intrinsic activity. Catalyst activities such as hydrodesulfurization (HDS), hydrodemetallization (HDM) and asphaltene conversion (HDAs), and hydrocracking conversions of a vacuum residue were evaluated. The highest hydrotreating and hydrocracking conversions were observed with the NiMo catalyst supported on mesoporous alumina. The results also supported that the catalyst that has a large pore diameter, high pore volume, and better active metals dispersion is highly desirable for the upgrading of a vacuum residue.
\end{abstract}

Keywords: SBA-15; mesoporous alumina; activated carbon; NiMo catalysts; vacuum residue; hydrotreating; hydrocracking

\section{Introduction}

Crude oils contain a significant number of extremely poor-quality heavy compounds. Indeed, there is a worldwide demand for low-sulfur, improved quality fuel oils and feedstocks for fluid catalytic cracking (FCC), and hydrocracking is continually increasing, while the available heavy crudes are becoming heavier [1-3]. Therefore, the refining processes that convert heavier crude oils into high value products are crucial to a refinery. However, the heaviest cuts, known as vacuum residues, contain a large amount of impurities such as metals, nitrogen, sulfur, and polyaromatic compounds. These are characterized as boiling above $550^{\circ} \mathrm{C}$, having high viscosity and specific gravity, and having high carbon residues and asphaltenes [1-4]. The presence of high molecular weight polyaromatic compounds and impurities in residues makes the upgrading of these feedstocks very difficult compared to lighter feeds.

The fixed-bed hydrotreatment (HDT) units are most commonly utilized for the residue upgrading. In these units, HDT is industrially performed at high-temperature and high-pressure (hydrogen) conditions with catalysts. Catalysts promote HDT reactions such as hydrodesulfurization (HDS), hydrodemetallization (HDM), hydrodenitrogenation (HDN), hydrogenation, and hydrocracking [3]. Therefore, the development of catalysts plays an important role in residue upgrading processes. 
Various studies were performed to prepare effective catalysts and to define active catalyst species, promoter roles, and optimum textural properties of the catalysts for the hydrotreatment of model compounds and lighter and heavier crude oil feedstocks [5-10]. In general, commercial catalysts consists of NiMo or CoMo metals supported on alumina. Studies have indicated that the nature of supports affects the catalyst activity for hydrotreatment reactions [7-11]. This might be due to several factors, such as sulfide phases of the catalyst, dispersion of active metals, interaction between the support and metals, textural properties, and acidity of the catalysts. Rana et al. $[7,8]$ compared the activities of the NiMo-supported catalyst using mixed oxides $\mathrm{Al}_{2} \mathrm{O}_{3}-\mathrm{MgO}, \mathrm{Al}_{2} \mathrm{O}_{3}-\mathrm{TiO}_{2}$, and $\mathrm{Al}_{2} \mathrm{O}_{3}-\mathrm{ZrO}_{2}$ as supports for the hydrotreatment of thiophene and cyclohexene model compounds. The results suggested that the catalyst with the highest acidity deactivates faster than the basic catalyst. Maity et al. [9] reported the use of alumina mixed with a US-Y zeolite as a support for the CoMo hydrotreating catalyst and activity tests were conducted using a Maya heavy crude oil. The authors concluded that the bi-modal type of pores present in the supported catalyst enhanced the HDS and HDM conversions, and acidic sites lead to the selective hydrocracking of asphaltenes. In addition, it was reported that the effectiveness of acidic catalyst is more at mild operating conditions. The authors also investigated the hydrotreating of Maya heavy crude oil using a carbon-modified alumina and found that the addition of carbon in the alumina matrix increases the pore diameter [11]. With an increase in the amount of carbon in the alumina, the average pore diameter of the support improved. The carbon-templated alumina catalyst with high porosity showed maximum heteroatoms removal activities. Recently, the activity of an alumina based CoMo-catalyst was investigated for the thiophene HDS reaction [12]. Improved textural properties of the support along with modified surface properties due to the addition of a pore-enlarging agent was proposed to be effective for the HDS of thiophene. The HDS conversion of the Mo based sulfided catalysts on organized mesoporous alumina support was demonstrated for HDS of benzothiophene [13]. It was observed that dispersion of Mo on support enhanced more than 1.5 times by using high surface area supports. The catalyst was found to be better than a reference industrial catalyst. The authors also studied the promotional effects of $\mathrm{Co}$ and $\mathrm{Ni}$ metals and found that the CoMo catalyst exhibited more than 50\% increase in hydrotreating activities.

The HDS activities of carbon-supported catalysts have been extensively studied for the model compounds, such as dibenzothiophene (DBT) and 4,6-dimethyldibenzothiophene (4,6-DMDBT) [14,15]. Typically, the carbon-supported catalysts have a higher DBT conversion than that of the alumina-supported catalysts. On the contrary, the sulfur removal from 4,6-DMDBT was observed to be lower than that of DBT with a carbon-supported catalyst, because of the unavailability of active sites to bulkier sulfur compounds by steric hindrance. The NiMo/CoMo HDS catalysts supported on activated carbon (AC) were also tested for the thiophene HDS [16-19]. The major advantages associated with AC are comparatively high surface area, low cost, and the possibility of modifying the surface of the catalysts. Brito et al. [17] tested the HDS activity of a NiMo/AC catalyst for the model compound, thiophene, and the results indicated that the type of thiomolybdate (molybdenum source) used for the catalyst synthesis significantly influenced the thiophene HDS activity. Kaluza and Zdrazil [18] reported that the carbon-supported catalysts were highly effective and more active than their alumina-supported catalysts for the HDS of thiophene. The authors described that up to a loading of $\sim 15 \% \mathrm{MoO}_{3}$, it is chemisorbed in a highly dispersed 'monolayer' form. The increase in activity by the activated carbons was not attributed to the high surface area.

The use of NiMo/SBA15 catalysts to investigate the HDS activity of thiophenic compounds was also extensively reported [20-23]. It was found that when SBA-15 was modified with citric acid to prepare the NiMo/SBA15 catalyst, dispersion of $\mathrm{MoS}_{2}$ particles was better [21]. The formation of the highest fraction of Mo-atoms on active surface of the catalysts was observed, resulting in the highest HDS conversion. Boahene et al. [24] demonstrated the influence of FeW/SBA15 catalysts for the hydrotreatment of heavy gas oil (from Athabasca bitumen) having $1.55 \mathrm{wt} . \%$ asphaltene. The authors found that the access of feedstock compounds to reach the catalytic active sites within the porous 
structure is a prime factor to study the effectiveness of the catalysts. The catalyst FeW/SBA15 with a pore diameter of $\sim 10 \mathrm{~nm}$ displayed the highest HDN and HDS activities during the hydrotreating process.

As discussed, the literature reports mainly demonstrated the HDS activity of the different supported NiMo/CoMo hydrotreating catalysts using model compounds as feedstock. However, when the actual heavy crude oils and residue feedstocks were treated with the reported catalysts, these catalysts were expected to behave differently. This happens because of the large amount of impurities in these feedstocks which adversely affect the active sites of the catalysts. Therefore, the objective of this research work was to compare the activities of the NiMo-catalyst supported on different supports such as SBA-15, activated carbon (AC), and mesoporous alumina $\left(\mathrm{Al}_{2} \mathrm{O}_{3}\right)$ for the upgrading of a real vacuum residue feedstock. The hydrotreating activities were evaluated in terms of HDS, HDM, and HDAs conversions. Comparisons between the catalytic activities were conducted based on the catalyst characteristics. The novelty of the present work is in providing information on how the textural and structural properties of different supported NiMo-catalysts affect the upgrading of a high-asphaltenic (22 wt. \%) vacuum residue.

\section{Materials \& Methods}

\subsection{Materials}

Tetraethylorthosilicate (TEOS), Pluronic F127, and Pluronic P123 were procured from Sigma-Aldrich. Aluminum isopropoxide, ammonium heptamolybdate (AHM), nickel nitrate, and carbon disulfide $\left(\mathrm{CS}_{2}\right)$ were procured from Alfa-Aesar.

\subsection{Methods}

\subsubsection{Catalytic Support Preparation}

The silica material (SBA-15) was prepared using TEOS as the silica source and a triblock copolymer (Pluronic P123) as the templating agent. To prepare SBA-15, $4 \mathrm{~g}$ of P123 was dissolved in $30 \mathrm{~g}$ deionized water and $120 \mathrm{~g}$ of a $2 \mathrm{M} \mathrm{HCl}$ solution at $40^{\circ} \mathrm{C}$ [25]. Then, $8.5 \mathrm{~g}$ of TEOS was slowly added into the solution. The resulting mixture was stirred at $40^{\circ} \mathrm{C}$ for $20 \mathrm{~h}$ and aged at $80^{\circ} \mathrm{C}$ for $48 \mathrm{~h}$. The solid product was recovered by filtration, washed with water, and then air-dried at $40^{\circ} \mathrm{C}$. The recovered solid was treated at $550{ }^{\circ} \mathrm{C}$ for $4 \mathrm{~h}$. To know the nature of synthesized sample whether it is SBA- 15 or amorphous silica, small angle X-ray diffraction (XRD) analysis was performed. The XRD spectra showed three well-resolved diffraction lines at $2 \theta, 0.9^{\circ}\left(\begin{array}{lll}1 & 0 & 0\end{array}\right), 1.6^{\circ}\left(\begin{array}{lll}1 & 1 & 0\end{array}\right)$, and $1.95^{\circ}(200)$. These diffraction lines were characteristics of the $p 6 \mathrm{~mm}$ hexagonal symmetry of SBA-15 [26].

Furthermore, mesoporous alumina $\left(\mathrm{Al}_{2} \mathrm{O}_{3}\right)$ was synthesized using Pluronic F127, a triblock copolymer, as a templating agent and aluminum isopropoxide as an aluminum source. In total, $1.8 \mathrm{~g}$ of Pluronic F127 was dissolved in ethanol $(46 \mathrm{~mL})$ and then $\mathrm{NH}_{4} \mathrm{OH}(9 \mathrm{~mL})$ was added into the solution at room temperature. The temperature was slowly increased to $70^{\circ} \mathrm{C}$. The whole mixture, with surfactant and $\mathrm{NH}_{4} \mathrm{OH}$, was stirred at $70{ }^{\circ} \mathrm{C}$ until it became clear, and then aluminum isopropoxide $(4.35 \mathrm{~g})$ was added. Next, the solution of nitric acid in water was added into the above mixture dropwise. The solvent-evaporation step was performed at $70^{\circ} \mathrm{C}$. The final solution became transparent, and the solution was cooled and aged for $10-12 \mathrm{~h}$ at $25^{\circ} \mathrm{C}$. The precipitate was recovered by filtration and washing with ethanol (2-3 times). The drying step was performed at $100^{\circ} \mathrm{C}$ for $16-18 \mathrm{~h}$. The calcination was performed at $5500^{\circ} \mathrm{C}$ for $4 \mathrm{~h}$.

The commercial activated carbon (AC) was procured from Toyo Engineering Corporation, Japan, and used to prepare the catalyst. The catalytic supports are cylindrical in shape, with a diameter of $1.9 \mathrm{~mm}$. 


\subsubsection{Catalyst Preparation}

The NiMo catalysts supported on different supports, i.e., $\mathrm{SBA}-15, \mathrm{AC}$, and $\mathrm{Al}_{2} \mathrm{O}_{3}$, were prepared and designated as $\mathrm{NiMo} / \mathrm{SBA} 15, \mathrm{NiMo} / \mathrm{AC}$, and $\mathrm{NiMo} / \mathrm{Al}_{2} \mathrm{O}_{3}$, respectively. The sequential impregnation method was used to prepare the catalyst. For $5 \mathrm{~g}$ of the support, $0.705 \mathrm{~g}$ of AHM and $0.6712 \mathrm{~g}$ of nickel nitrate salts were utilized to prepare solutions in deionized water. The aqueous solutions having metal salts were impregnated into the dried supports (dried at $105^{\circ} \mathrm{C}$ for $4 \mathrm{~h}$ ). The impregnated catalyst was dried for $6 \mathrm{~h}$ at $110^{\circ} \mathrm{C}$, and after drying, calcination was performed at $450{ }^{\circ} \mathrm{C}$ for $4 \mathrm{~h}$. These catalysts contain $3 \mathrm{wt} . \% \mathrm{NiO}$ and $10 \mathrm{wt} . \% \mathrm{MoO}_{3}$ on the catalyst basis.

\subsubsection{Catalyst Characterization}

The BET specific surface area, pore-volume, and pore size distribution (PSD) were analyzed by nitrogen-sorption analysis at 77K (BEL MAXSORP). The samples were degassed at $300^{\circ} \mathrm{C}$ for $2 \mathrm{~h}$. $\mathrm{X}$-ray diffraction (XRD) analysis of the catalysts was conducted using a Bruker AXZ GMBH with $\mathrm{Cu}$ $\mathrm{K} \alpha$ radiation $(\lambda=0.15418 \mathrm{~nm})$. Transmission electron microscopy (TEM) analysis was conducted using a Jeol JEM, 2100 microscope operated at $200 \mathrm{kV}$. To perform TEM, a sulfided catalyst was sonicated in n-heptane, and a drop of the sample was placed onto a copper grid coated with a sputtered carbon polymer. The $\mathrm{MoS}_{2}$ slab lengths (average) were determined using formula:

$$
\text { Slab length }=\frac{\sum_{i=1}^{n} \text { Lixi }}{\sum_{i=1}^{n} x i}
$$

where $i$ is the total number of $\mathrm{MoS}_{2}$ slabs, $L_{i}$ is the length of a MoS ${ }_{2}$ unit, and $x_{i}$ is the number of $\mathrm{MoS}_{2}$ slabs, of which the slab length is $L_{i}$ [27].

\subsubsection{Catalyst Activation and Performance Evaluation}

The activation of the prepared catalysts was carried out by ex-situ sulfidation prior to the catalyst activity tests. For this activation, an atmospheric unit was utilized. In this system, hydrogen was passed through a container having $\mathrm{CS}_{2}$, and then the saturated mixture of $\mathrm{CS}_{2}$ with hydrogen was passed through a reactor. The sulfidation was conducted at $400{ }^{\circ} \mathrm{C}$ temperature under atmospheric pressure for $4 \mathrm{~h}$.

A high-temperature and high-pressure batch reactor, having a one-liter capacity, was used to test the activity of the prepared catalysts. A vacuum residue (VR) was utilized as a feedstock in a semi-solid form at room temperature. Therefore, before the actual run, the feedstock was heated at $120^{\circ} \mathrm{C}$ in an oven and $200 \mathrm{~g}$ of this feed was transferred to the reactor vessel. Next, the sulfided catalyst $(2 \mathrm{~g})$ was packed into a catalyst basket and placed inside the reactor vessel. The reactor was then sealed and checked with nitrogen for any leakage. The required amount of hydrogen was added into the reactor so that the final pressure reached $10 \mathrm{MPa}$ at the desired reaction temperature $\left(410^{\circ} \mathrm{C}\right)$ with a heating rate of $3{ }^{\circ} \mathrm{C} / \mathrm{min}$. Stirring was applied when the reactor temperature reached $410^{\circ} \mathrm{C}$, and the time was recorded as the starting point of the reaction. The optimized reaction conditions were used for this study as described in the research group's previous publications [28-30]. After the reaction, the reactor was cooled to room temperature at a normal cooling rate. The liquid product was poured into a glass bottle, and the solid (having the catalyst and solid product) was carefully recovered from the catalyst basket. The liquid product was analyzed for $\mathrm{CHN}$, sulfur (S), metals, and the product distribution as per the methods is explained in Section 2.2.5. The hydrotreating conversions were calculated as:

$$
H D X, \%=\frac{X \text { feed }-X \text { product }}{X \text { feed }} \times 100
$$

where $X$ represents sulfur, metals, and asphaltenes; thus, the hydrotreating conversions such as HDS, $\mathrm{HDM}$, and asphaltene conversions (HDAs) were calculated. 
The residue conversion, i.e., conversion of the fractions boiling above $550{ }^{\circ} \mathrm{C}$, is calculated using the following equation:

$$
\text { Residue conversion, } w t \%=\frac{\left(g \text { of } 550^{\circ} \mathrm{C}+\text { in feed }-g \text { of } 550^{\circ} \mathrm{C}+\text { in product }\right)}{\left(g \text { of } 550^{\circ} \mathrm{C}+\text { in feed }\right)} \times 100
$$

where $g$ of $550{ }^{\circ} \mathrm{C}+$ in feed and $\mathrm{g}$ of $550{ }^{\circ} \mathrm{C}+$ in product is the amount of $550{ }^{\circ} \mathrm{C}+$ fraction present in feed and in the product in grams, respectively. The solid sample was washed with toluene, dried at $110^{\circ} \mathrm{C}$ for $6 \mathrm{~h}$.

\subsubsection{Analysis of Feed and Products}

The density and viscosities of the feed and liquid hydrocarbons were analyzed with a viscometer SVM 3000 (Anton Paar). The amount of metals ( $\mathrm{Ni}$ and $\mathrm{V}$ ) were analyzed by inductive coupled plasma atomic emission spectroscopy (ICP-AES) using a Leeman DRE PS-3000UV instrument. ASTM D-874 was used for sample preparation for the metal analysis. The sulfur content was determined with an Oxford sulfur analyzer (Lab-X 3500). An Elemental Vario Micro CHN analyzer was used to measure the elements such as carbon $(\mathrm{C})$, hydrogen $(\mathrm{H})$, and nitrogen $(\mathrm{N})$. ASTM D-3279 was performed to determine the asphaltene content. The hydrocarbon analysis, i.e., saturates (S), aromatics (A), and resins $(\mathrm{R})$, was performed using ASTM D-4124. The product distribution of the liquid hydrocarbons was performed using a thermogravimetric analyzer (TGA), and the details of the method were provided in published works [28-30]. Coke content was analyzed by TGA (Perkin Elmer TGA4000). For this analysis, $10-12 \mathrm{mg}$ of the catalyst was placed in a platinum crucible, and the sample was heated from 25 to $900{ }^{\circ} \mathrm{C}$ with heating rate of $10^{\circ} \mathrm{C} / \mathrm{min}$ in the presence of air $(50 \mathrm{~mL} / \mathrm{min})$.

\section{Results}

\subsection{Catalyst Characterization}

Nitrogen-sorption and XRD analysis were performed on all the prepared catalysts before sulfidation. Nitrogen-sorption isotherms and PSDs of all prepared catalysts are shown in Figures 1 and 2. For all three catalysts, isotherms are Type IV (IUPAC designation), which confirms the presence of mesopores. A steep hysteresis loop is observed from the $\mathrm{N}_{2}$-sorption curves (Figure 1) that exhibits capillary condensation and evaporation [31]. This hysteresis loop is an $\mathrm{H}_{1}$ type for NiMo/SBA15, which confirms the presence of interconnected irregular ink-bottle type pores. For the NiMo/AC catalyst, an $\mathrm{H}_{3}$ type of hysteresis is seen indicating that the slit-like pores are present. However, the $\mathrm{H}_{2(\mathrm{a})}$ type hysteresis loop is noticed for the $\mathrm{NiMo} / \mathrm{Al}_{2} \mathrm{O}_{3}$ catalyst suggesting their uniform cylindrical pores [32]. 

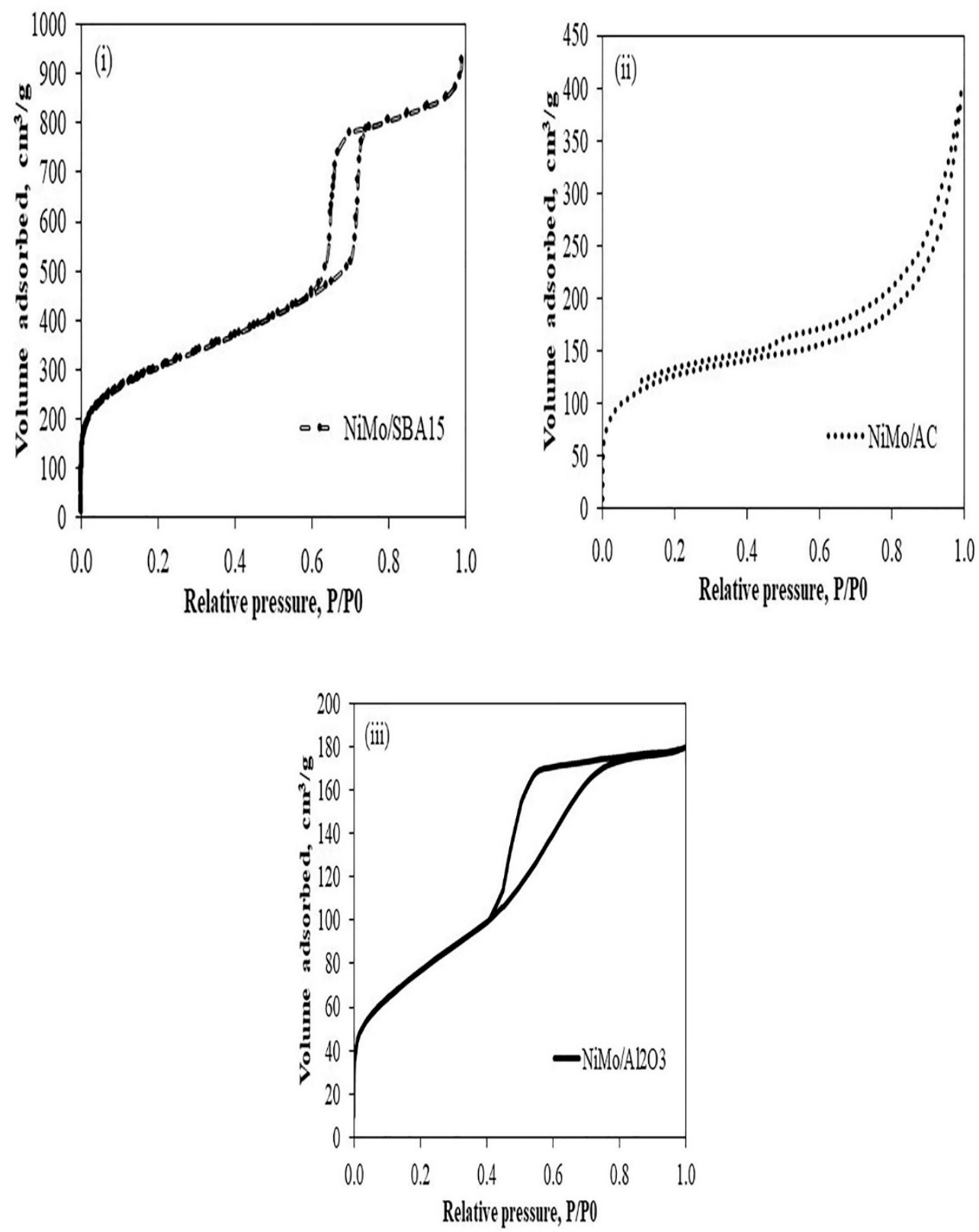

Figure 1. Nitrogen-sorption isotherms of the prepared NiMo catalysts: (i) NiMo/SBA15 catslyst, (ii) $\mathrm{NiMo} / \mathrm{AC}$ catalyst, (iii) $\mathrm{NiMo} / \mathrm{Al} 2 \mathrm{O} 3$ catalyst.

Comparing the isotherms in Figure 1i-iii, one may easily observe the difference in textural properties between these catalysts. The $\mathrm{NiMo} / \mathrm{Al}_{2} \mathrm{O}_{3}$ catalyst has a highest pore diameter and pore volume as observed from Figure 2iii. Table 1 presented the textural parameters of the NiMo catalysts. SBA-15 and activated carbon-supported NiMo catalysts possess a very high surface area compared to the mesoporous alumina-supported NiMo catalyst. These catalysts also contain micropores. The NiMo/ $/ \mathrm{Al}_{2} \mathrm{O}_{3}$ catalyst possesses a higher pore diameter and pore volume with an appropriate surface area, which is desirable for the residue upgrading. 

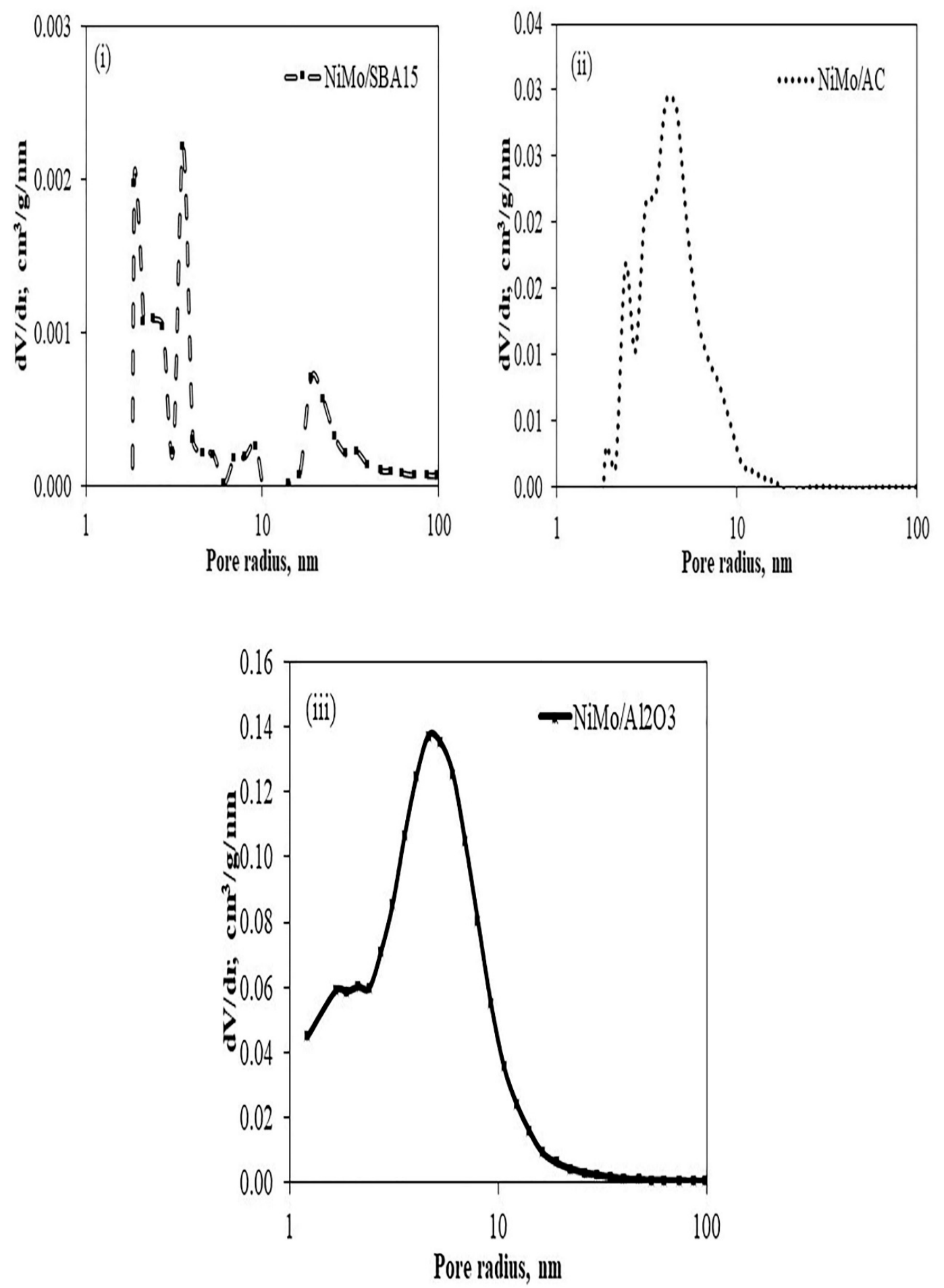

Figure 2. The pore size distribution of the prepared NiMo catalysts: (i) NiMo/SBA15 catslyst, (ii) $\mathrm{NiMo} / \mathrm{AC}$ catalyst, (iii) $\mathrm{NiMo} / \mathrm{Al}_{2} \mathrm{O}_{3}$ catalyst.

Table 1. Textural parameters of the prepared NiMo catalysts.

\begin{tabular}{cccc}
\hline Properties & NiMo/SBA15 & NiMo/AC & NiMo/Al $\mathbf{O}_{\mathbf{3}}$ \\
\hline $\mathrm{S}_{\mathrm{BET}}, \mathrm{m}^{2} / \mathrm{g}$ & 573 & 447 & 276 \\
\hline Pore volume, $\mathrm{cm}^{3} / \mathrm{g}$ & 0.67 & 0.62 & 1.08 \\
\hline Pore diameter, $\mathrm{nm}$ & 1.87 & 5.49 & 10.02 \\
\hline
\end{tabular}


Powder X-ray diffraction (XRD) is a powerful instrument utilized to get information regarding the dispersion of active metals in the hydrotreating catalysts. XRD of three supported catalysts is presented in Figure 3. XRD spectra indicates the amorphous nature of the supports. In general, diffraction lines at

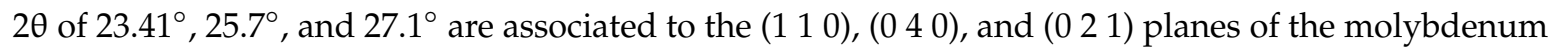
oxide $\left(\mathrm{MoO}_{3}\right)$ [33]. The diffraction lines for $\mathrm{MoO}_{3}$ phases were not observed in all three catalysts. Two weak lines at $2 \theta=42^{\circ}(150)$ and $49^{\circ}(002)$ in NiMo/SBA15 may be due to the crystalline $\mathrm{MoO}_{3}$. Similarly, a broad diffraction line around $2 \theta=26^{\circ}$ is noticed for the AC-supported catalyst. This could be caused by the graphene or the bulk $\mathrm{MoO}_{3}$. However, no such line is observed for the $\mathrm{NiMo} / \mathrm{Al}_{2} \mathrm{O}_{3}$ catalyst and this catalyst showed only $\gamma-\mathrm{Al}_{2} \mathrm{O}_{3}$ diffraction lines at $2 \theta$ of $46^{\circ}$ and $67^{\circ}$ [34]. It can be said from these $\mathrm{XRD}$ results that $\mathrm{MoO}_{3}$ is well dispersed into the mesoporous alumina, whereas the presence of bulk $\mathrm{MoO}_{3}$ is observed for the SBA15-supported catalyst. $\mathrm{MoO}_{3}$ may also present in the AC-supported catalyst. Because of the low amount of Ni used, no peak was seen for Ni-based phases.

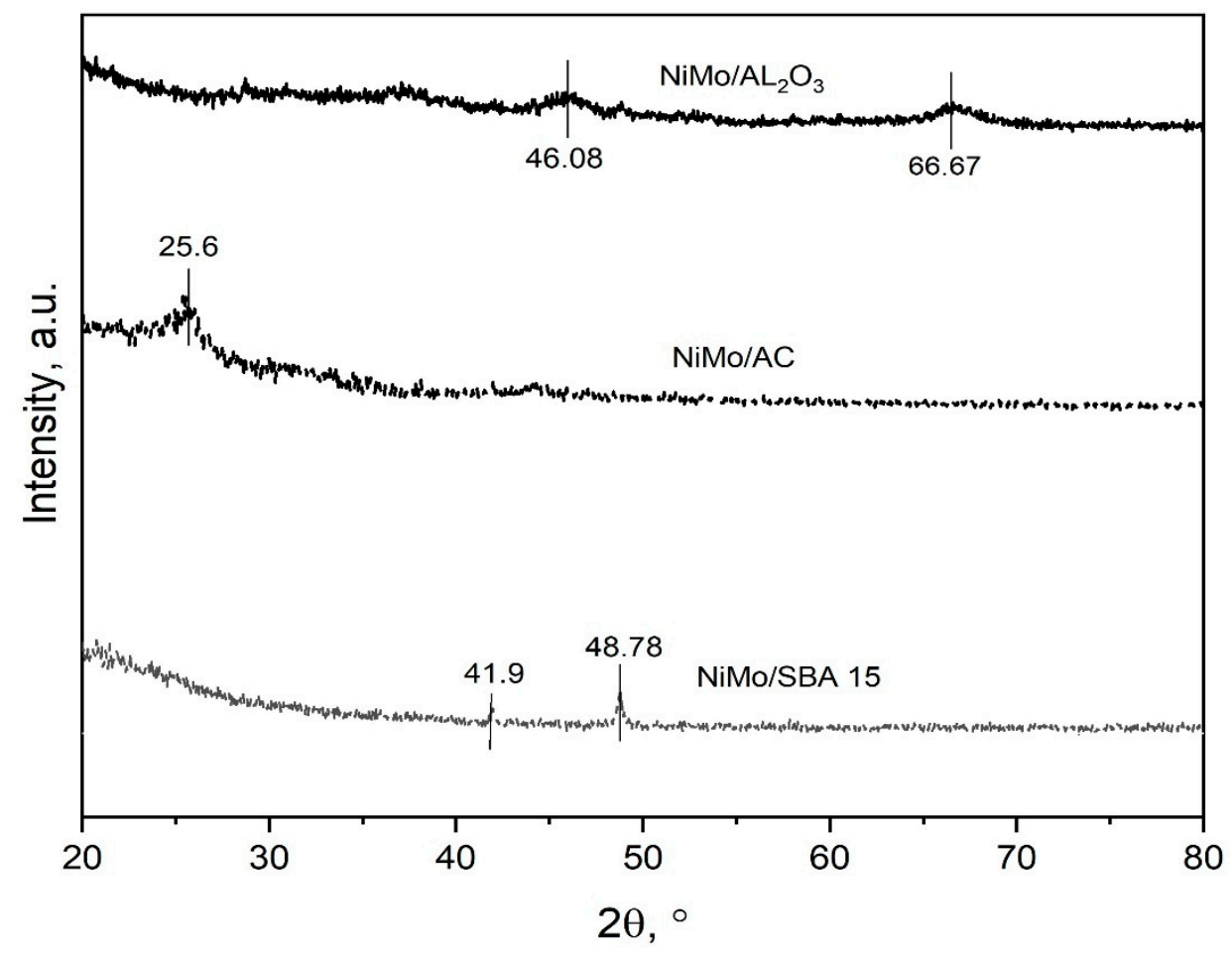

Figure 3. X-ray diffraction (XRD) diffractogram of the NiMo catalysts.

Overall, in the XRD spectra, prepared catalysts showed weak and broad peaks indicating the small particle sizes and high dispersion of metals ( $\mathrm{Ni}$ and Mo). The higher metal dispersion lead to the generation of more active catalytic sites and the adsorption of more hydrogen. This leads to increased catalyst activity in the case of a hydrotreating reaction [33].

TEM analyses of NiMo-sulfided catalysts were performed to collect information about the dispersion of molybdenum sulfide $\left(\mathrm{MoS}_{2}\right)$ on supports. The TEM images are presented in Figure 4 . The presence of the active $\mathrm{MoS}_{2}$ phase (arrow) is noticeable for the $\mathrm{NiMo} / \mathrm{Al}_{2} \mathrm{O}_{3}$ and $\mathrm{NiMo} / \mathrm{AC}$ catalysts. However, $\mathrm{MoS}_{2}$ fringes were not observed in the NiMo/SBA 15 catalyst (Figure 4iii). The presence of two to three stacking of $\mathrm{MoS}_{2}$ is noticeable in the $\mathrm{NiMo} / \mathrm{Al}_{2} \mathrm{O}_{3}$ catalyst, which may be type II active sites. However, this type of active sites was not visible for the AC-supported catalyst. The calculated average slab length for $\mathrm{NiMo} / \mathrm{Al}_{2} \mathrm{O}_{3}$ catalyst was $3.19 \mathrm{~nm}$. This large average slab length can be associated with the weaker metal-support interaction in $\mathrm{NiMo} / \mathrm{Al}_{2} \mathrm{O}_{3}$ catalyst. The Ni-Mo-S model, as explained by Topsoe [35], was used mainly to understand the influence of the hydrotreating catalysts. Based on the nature of metal-support interactions, two types (type I and type II) of the Ni-Mo-S structure is present. The type I active sites consist of strong interactions between the metal and support and showed low 
intrinsic activity. On the other hand, type II Ni-Mo-S phases have weak interactions between the metal and support and have high intrinsic activity [36].
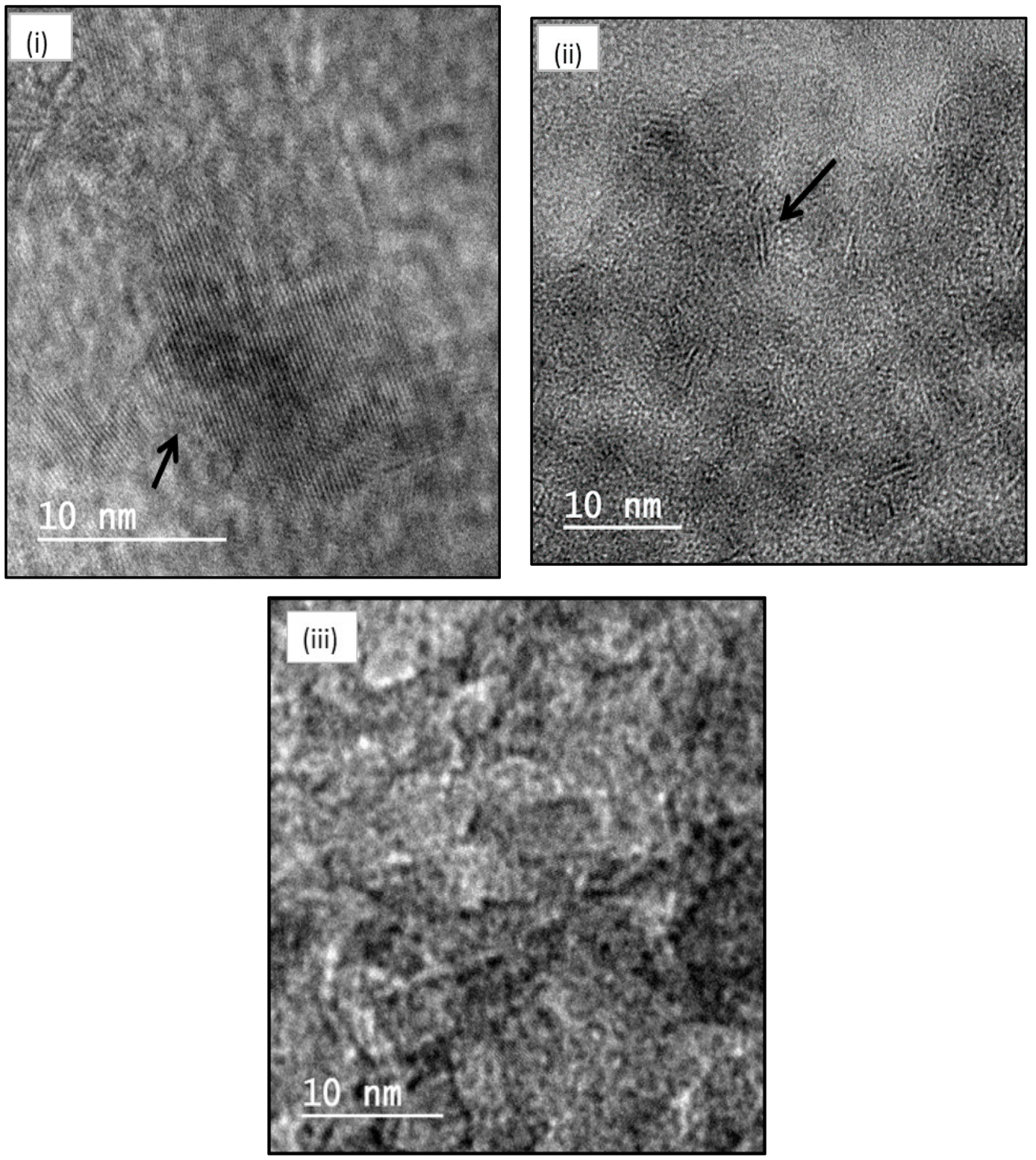

Figure 4. Transmission electron microscopy (TEM) images of the prepared NiMo catalysts (i) NiMo/AC, (ii) $\mathrm{NiMo} / \mathrm{Al}_{2} \mathrm{O}_{3}$, and (iii) $\mathrm{NiMo} / \mathrm{SBA} 15$ (arrow shows the presence of $\mathrm{MoS}_{2}$ ).

\subsection{Catalysts Activity Studies}

The hydrotreating activities were evaluated in a batch reactor using VR as feedstock. Because all the reactions were performed under nearly the same conditions, the differences in the conversions were attributed mainly to the nature of the catalyst employed. Properties of the feedstock are listed in Table 2. VR contains high asphaltene (22 wt.\%), sulfur (5.45 wt.\%), and metal contents ( $\mathrm{Ni}+\mathrm{V}=305 \mathrm{wppm})$. 
Table 2. Properties of the vacuum residue (VR) feedstock and hydrotreated products.

\begin{tabular}{lcccc}
\hline \multicolumn{1}{c}{ Properties } & VR & NiMo/SBA15 & NiMo/AC & NiMo/Al $_{\mathbf{2}} \mathbf{O}_{3}$ \\
\hline Density at $15.6{ }^{\circ} \mathrm{C}$, g/mL & 1.055 & 0.8624 & 0.9447 & 0.8529 \\
Kinematic viscosity at $15.6{ }^{\circ} \mathrm{C}$, cSt & $25,794 *$ & 7.12 & 4.50 & 2.74 \\
Sulfur, wt. $\%$ & 5.45 & & & \\
Ni, wppm & 65 & - & - & - \\
V, ppm & 240 & - & - & - \\
H/C, atomic ratio & 1.07 & 1.32 & 1.41 & 1.67 \\
MCR, wt.\% & 26.29 & 5.65 & 2.73 & 3.26 \\
Saturate, wt.\% & 8.89 & 12.27 & 40.64 & 64.46 \\
Aromatic, wt.\% & 25.88 & 51.68 & 30.93 & 25.54 \\
Resin, wt. $\%$ & 43.25 & 27.39 & 24.65 & 8.53 \\
Asphaltene, wt.\% & 21.98 & 8.66 & 3.78 & 1.47 \\
Coke, wt. $\%$ & - & 47.01 & 39.55 & 29.65 \\
\hline
\end{tabular}

${ }^{*}=$ at $100{ }^{\circ} \mathrm{C}$, Reaction conditions: temperature $=410^{\circ} \mathrm{C}$, pressure $=10 \mathrm{MPa}$, and time $=6 \mathrm{~h}$.

\subsubsection{Hydrotreating Activities}

In Figure 5, hydrotreating activities such as HDS, HDM, and HDAs of the different NiMo catalysts have been presented. The HDS conversion obtained with $\mathrm{NiMo} / \mathrm{SBA} 15, \mathrm{NiMo} / \mathrm{AC}$, and $\mathrm{NiMo} / \mathrm{Al}_{2} \mathrm{O}_{3}$ catalysts were 51,61 , and $70 \%$, respectively. The NiMo catalyst supported on alumina had the highest HDS conversion.

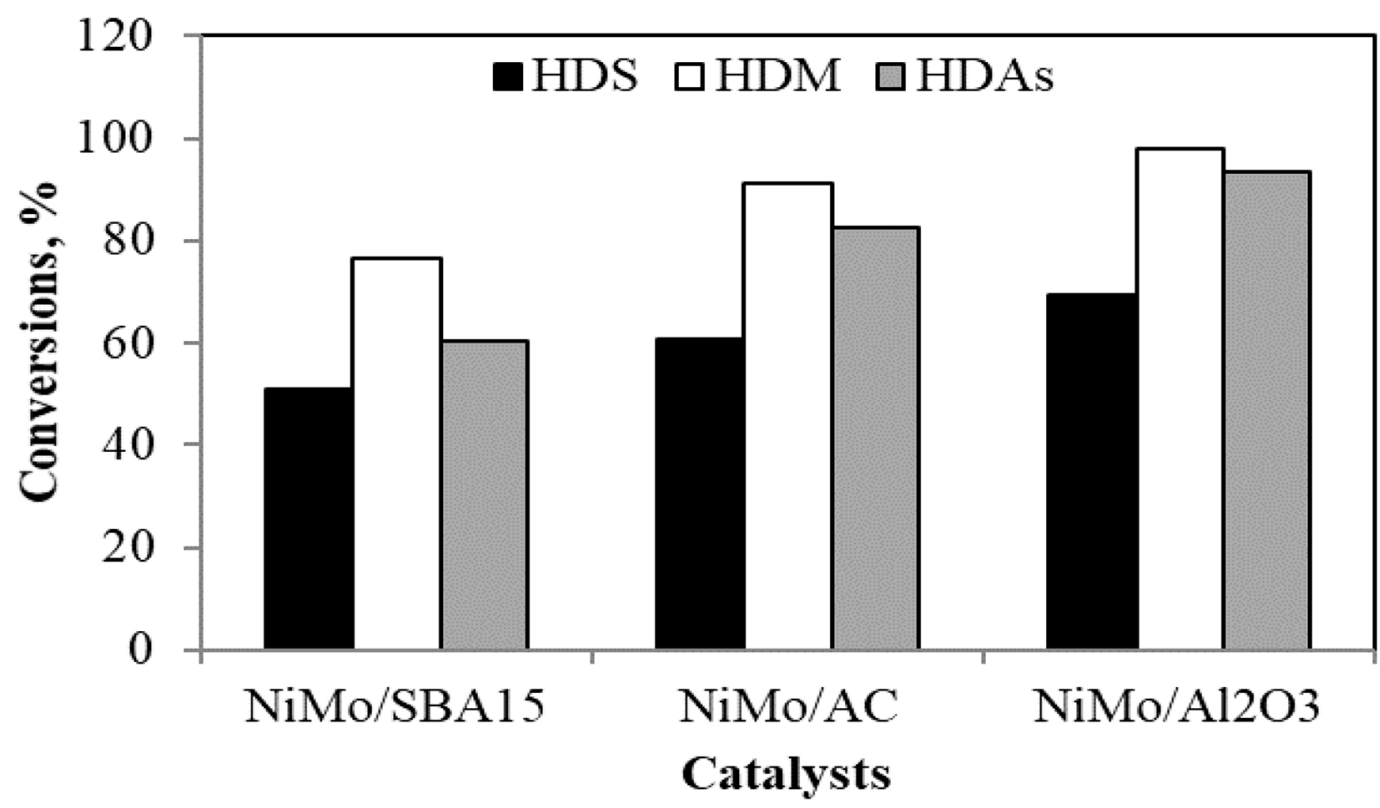

Figure 5. Hydrotreating conversions by the NiMo catalysts. (HDS = Hydrodesulfurization; $\mathrm{HDM}=$ Hydrodemetallization; and HDAs = Asphaltene conversion).

The metal $(\mathrm{Ni}+\mathrm{V})$ removal efficiency or $\mathrm{HDM}$ of $\mathrm{NiMo} / \mathrm{SBA} 15, \mathrm{NiMo} / \mathrm{AC}$, and $\mathrm{NiMo} / \mathrm{Al}_{2} \mathrm{O}_{3}$ catalysts were 77,91 , and $97 \%$, respectively. Figure 5 shows that HDM activities are higher compared to those of the HDS. The reason is that HDM reaction mechanism depends on the $\mathrm{H}_{2} \mathrm{~S}$ partial pressure, as documented in the literature [37,38]. During the hydroprocessing reaction, $\mathrm{H}_{2} \mathrm{~S}$ is generated and accumulates inside the batch reactor. With reaction time, $\mathrm{H}_{2} \mathrm{~S}$ concentration increases at the cost of the reactive hydrogen. The increase in $\mathrm{H}_{2} \mathrm{~S}$ concentration had a positive effect on the $\mathrm{HDM}$, but a negative effect on HDS. Rana et al. [38] proposed a reaction mechanism for $\mathrm{HDM}$ with added $\mathrm{H}_{2} \mathrm{~S}$. The proposed mechanism involves these steps: (i) proton addition to the metal-porphyrin ring, (ii) hydrogenation of the ring that delocalizes the electron density and forms the chlorin structure, and (iii) hydrogenolysis of the metal-nitrogen bond. The first two steps can occur without the catalyst at a high $\mathrm{H}_{2} \mathrm{~S}$ and $\mathrm{H}_{2}$ 
pressure. A catalyst is required mainly for the third step, hydrogenolysis of metal-nitrogen bond in porphyrin structure. It has been proposed that at high $\mathrm{H}_{2} \mathrm{~S}$ partial pressure, sulfhydryl groups may favor hydrogenation via the donation of protons to the porphyrin and form intermediate metal-chlorin structure [38]. Therefore, HDM activity is enhanced by the presence of $\mathrm{H}_{2} \mathrm{~S}$.

VR used for the present study was highly asphaltenic; therefore, a significant amount of coke deposition on the catalysts was expected during the reaction. It is well reported that asphaltenes are the major cause for the coke deposition on the catalysts [28-30]. Therefore, the asphaltene conversion (HDAs) of the catalysts was evaluated and is shown in Figure 5. The results showed that the NiMo/AC and $\mathrm{NiMo} / \mathrm{Al}_{2} \mathrm{O}_{3}$ catalysts were highly active for HDAs. The trend of HDAs activities is almost like that of the HDM activities, suggesting that metal-bearing compounds were mostly associated with an asphaltenic structure, and therefore, the conversion of metal and asphaltene follows a similar trend.

The NiMo/ $/ \mathrm{Al}_{2} \mathrm{O}_{3}$ catalyst shows higher activity for hydrotreating conversions. The reason is that the $\mathrm{NiMo} / \mathrm{Al}_{2} \mathrm{O}_{3}$ catalyst has a sufficiently higher pore diameter (Table 1), so that the bigger size metal- and asphaltene-containing molecules have access to the catalyst active sites and are easily cracked. Moreover, the total pore volume of alumina is also very high, which can accommodate a maximum quantity of metals and asphaltene molecules. These results indicate that the average pore diameter and total pore volume of the catalysts play a promising role in asphaltene (HDAs) and metal (HDM) removal.

\subsubsection{Hydrocracking Activities}

The hydrocracking activities in terms of residue conversion and product distribution were studied using $\mathrm{NiMo} / \mathrm{SBA}-15, \mathrm{NiMo} / \mathrm{AC}$, and $\mathrm{NiMo} / \mathrm{Al}_{2} \mathrm{O}_{3}$ catalysts. The results are presented in Figure 6 . The literature reports explained that the upgrading of the $>550{ }^{\circ} \mathrm{C}$ fraction in VR is a thermally driven process $[39,40]$. In the present study, the large difference that was observed between catalysts indicated that the process is catalytically controlled. The catalytic performance in terms of the residue conversion was: $\mathrm{NiMo} / \mathrm{SBA} 15<\mathrm{NiMo} / \mathrm{AC}<\mathrm{NiMo} / \mathrm{Al}_{2} \mathrm{O}_{3}$.

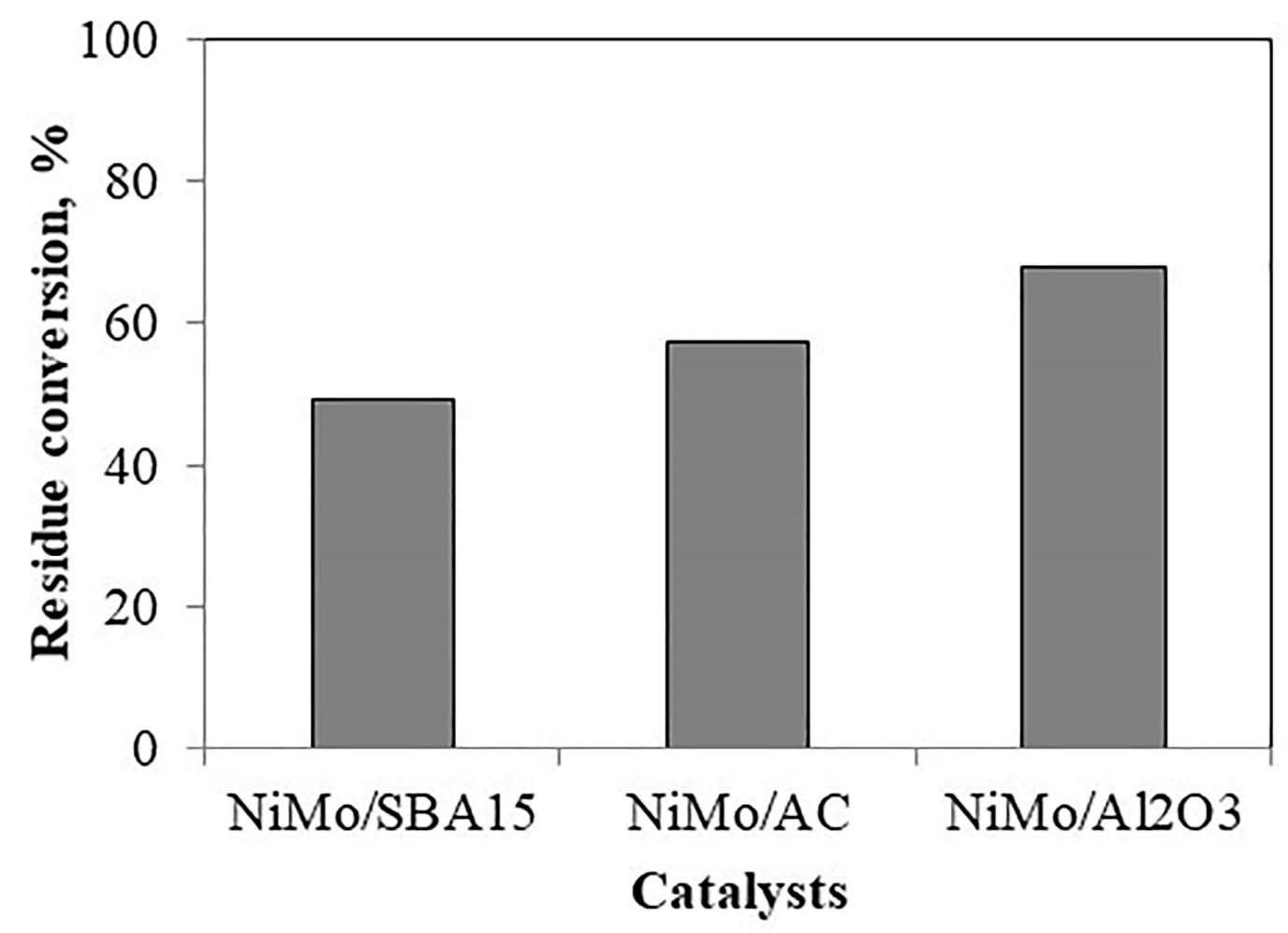

Figure 6. Residue conversion of NiMo-catalysts. 
The hydrotreated products were also fractionated into four distillates: naphtha $\left(<150{ }^{\circ} \mathrm{C}\right)$, middle distillates $\left(150-350{ }^{\circ} \mathrm{C}\right)$, vacuum gas oil $\left(350-550{ }^{\circ} \mathrm{C}\right)$, and residue $\left(>550{ }^{\circ} \mathrm{C}\right)$. The product distribution of liquid products is shown in Figure 7. The naphtha yields are found to be very low in the SBA-15- and AC-supported catalysts compared to alumina-supported NiMo-catalysts. The middle distillates and vacuum gas oil (VGO) fraction yields are quite similar to the NiMo/SBA15 and NiMo/AC catalysts. On the contrary, the $\mathrm{NiMo} / \mathrm{Al}_{2} \mathrm{O}_{3}$ catalyst displayed a better yield of lower boiling materials, i.e., $31 \%$ naphtha and $54 \%$ middle distillates. The unconverted residue is also very low with the $\mathrm{NiMo} / \mathrm{Al}_{2} \mathrm{O}_{3}$ catalyst but high by using the NiMo/SBA15 catalyst.

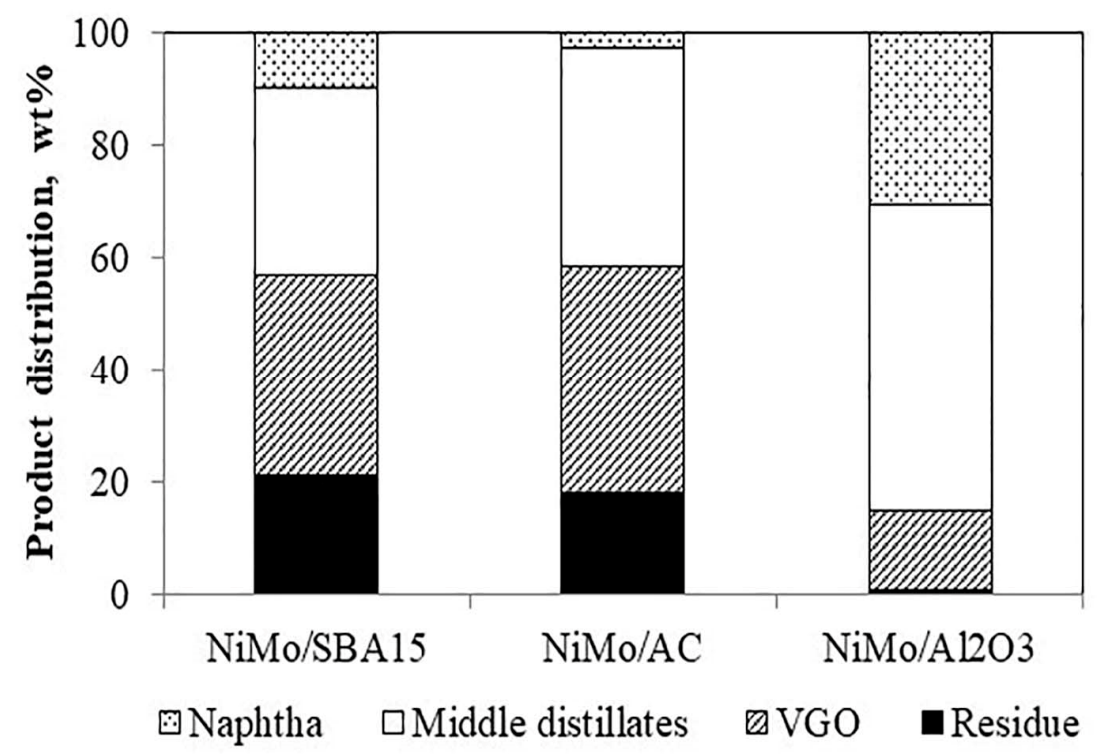

Figure 7. Product distribution of the hydrotreated products obtained after the reaction of vacuum residue with NiMo-catalysts (VGO = vacuum gas oil).

In Table 2, the densities, viscosities, and the hydrogen/carbon $(\mathrm{H} / \mathrm{C})$ ratios of the liquid products are presented. The hydrotreating results demonstrated that on upgrading VR with a $\mathrm{NiMo} / \mathrm{Al}_{2} \mathrm{O}_{3}$ catalyst, viscosity falls drastically to $2.74 \mathrm{cSt}$ (at $15.6^{\circ} \mathrm{C}$ ) relative to $25,794 \mathrm{cSt}$ (at $100{ }^{\circ} \mathrm{C}$, Table 2) of the feed. The reason is that the catalyst possesses bifunctional character, i.e., cracking occurs by alumina support and hydrogenation takes place by the dispersed metals Ni/Mo. The H/C ratio obtained with the $\mathrm{NiMo} / \mathrm{Al}_{2} \mathrm{O}_{3}$ catalyst was high (1.67), proving that the catalyst possesses higher hydrogenation functionality.

Saturates, aromatics, resins, and asphaltenes (SARA) analysis of the feed as well as its hydrotreated products were performed, and the data is shown in Table 2. In general, during the hydrocracking reactions, the asphaltenes are converted to resins and resins converted to aromatics [28-30]. The table shows that the asphaltenes were mainly cracked to form resin (27 wt.\%) and aromatic (52 wt.\%) fractions with a NiMo/SBA15 catalyst. As in this catalyst, the pore size distributions are very low (Table 1); therefore, access of the large asphaltene molecules to active sites is restricted, thus, condensation reactions may occur leading to the formation of more condensed aromatic structures. With $\mathrm{NiMo} / \mathrm{AC}$ catalyst, $41 \mathrm{wt} . \%$ of saturates were produced, but this amount is less compared with the $\mathrm{NiMo} / \mathrm{Al}_{2} \mathrm{O}_{3}$ catalyst. The amount of saturates $(65 \mathrm{wt} . \%)$ produced was very high with the $\mathrm{NiMo} / \mathrm{Al}_{2} \mathrm{O}_{3}$ catalyst. Increased saturate fractions might result due to the better hydrogenation function of the $\mathrm{NiMo} / \mathrm{Al}_{2} \mathrm{O}_{3}$ catalyst, which helps in terminating the long-chain radical molecules, thus inhibiting the condensation reactions.

It is well established that asphaltenes present in the VR lead to coke formation. Table 2 shows that a considerable amount of coke was formed with the NiMo/SBA15 catalyst. Thus, the lowest residue conversion (shown in Figure 6) was obtained with this catalyst. The lowest amount of coke was formed with the $\mathrm{NiMo} / \mathrm{Al}_{2} \mathrm{O}_{3}$ catalyst. 


\subsection{Spent Catalyst Characterization}

After the completion of the reaction, the catalyst was removed from the catalyst basket. The recovered catalyst was then cleaned with toluene using the soxhlet process. The coke deposits (toluene insoluble) on the catalyst was characterized by the TGA. The derivatives of weight loss with temperature are presented in Figure 8. Two prominent weight losses around $100{ }^{\circ} \mathrm{C}$ and $380-700{ }^{\circ} \mathrm{C}$ were noticed for all the derivative curves. The second peak in the temperature range of $380-700{ }^{\circ} \mathrm{C}$ is very sharp and prominent. However, the peak for the second weight loss is not identical for all catalysts. The first weight loss peak is because of the loss of lighter hydrocarbon or water trapped inside the pore cavity of the spent catalyst. On the other hand, the second weight loss peak is due to coke burning. Begon et al. [41] reported that coke burned at lower and higher temperatures is designated as soft and hard coke, respectively. The coke deposited on the NiMo/SBA15 spent catalyst is hard in nature, as the weight loss $\left(26 \mathrm{wt} . \%\right.$ in the range $\left.350-650{ }^{\circ} \mathrm{C}\right)$ due to coke burning occurs at a relatively high temperature. Two types of carbon were detected in the NiMo/AC spent catalyst. The support of this catalyst is carbon, and carbon (coke) from the feedstock is also deposited on the catalyst. A wide, broad peak (weight loss $77 \mathrm{wt} . \%$ ) for this catalyst reveals that these two carbons are indistinguishable. Moreover, the figure shows that the end temperature $\left(700^{\circ} \mathrm{C}\right)$ of the coke burning peak for $\mathrm{NiMo} / \mathrm{AC}$ catalyst is slightly higher compared with the rest of the catalysts. The carbon support in the NiMo/AC catalyst is hard, and therefore, it is combusted at a higher temperature. While the coke deposited on the alumina-supported catalyst shows two temperature maxima at around 506 and $591^{\circ} \mathrm{C}$. The second peak in this case is comparatively broad. Both soft (at $506^{\circ} \mathrm{C}$ ) and hard $\left(\right.$ at $\left.591{ }^{\circ} \mathrm{C}\right)$ cokes were produced with an alumina-supported catalyst $\left(\mathrm{NiMo} / \mathrm{Al}_{2} \mathrm{O}_{3}\right)$, but the amount of soft coke $(19 \mathrm{wt} . \%)$ is greater than the hard coke (8 wt.\%).

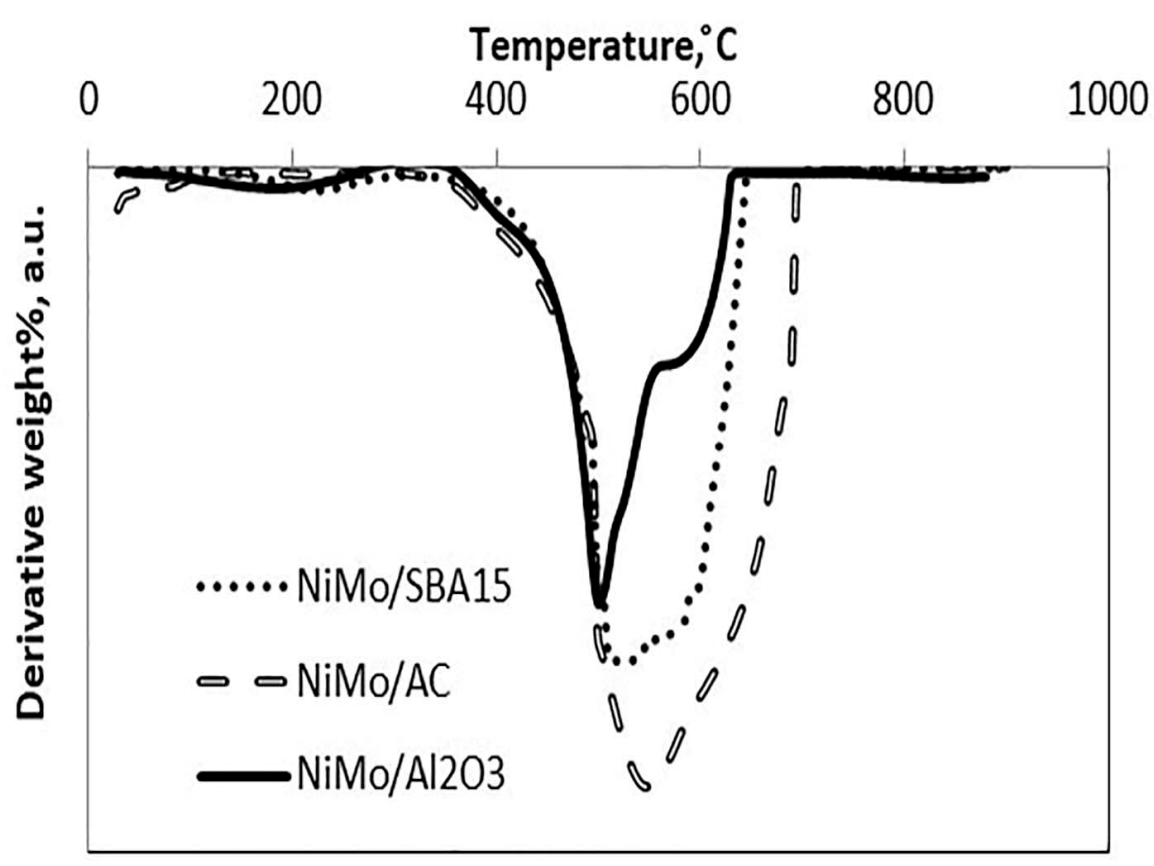

Figure 8. Derivative of thermogravimetric (DTG) curves of spent catalysts.

\section{Discussion}

The vacuum residue used in the presented work contains a very high concentration of complex hydrocarbons, such as microcarbon residues and asphaltenes. Therefore, for the effective conversion of larger hydrocarbons, catalytic support must possess wide channels (pores) so that these molecules can access the active sites and hence are cracked into smaller hydrocarbons. Because of this, the support that possesses an average pore size and a higher pore volume is always desirable for residue conversion. On the other hand, an extremely high average pore diameter can have a negative effect on metal 
dispersion. For better metal dispersion, a large surface area is required. However, the average pore diameter is inversely proportional to the surface area, meaning that the supports that possess a high pore diameter have a low surface area. As the active metal (Mo) loading for the residue hydrotreating catalysts is very low, the high-surface-area support is not essential.

The effect of mesoporous supports (silica, activated carbon, and $\gamma-\mathrm{Al}_{2} \mathrm{O}_{3}$ ) on the hydrotreating activity of NiMo catalysts was studied using VR as feed. At a high temperature, the hydrocracking reactions occur because of both thermal cracking and hydrogenation reactions. In catalytic cracking, a catalyst not only promotes the hydrogenation of the free radicals, but also suppresses the cracking and polymerization reactions. Therefore, the catalyst inhibits the generation of undesirable products such as coke and gases.

A comparative performance reveals that, although a silica-supported catalyst possesses a high surface area, because of its low pore size, it is highly prone to coke formation during residue upgrading. The access of larger microcarbon residue and asphaltene molecules is restricted to the active sites. This in turn leads to poor conversions and a low yield of liquid products. It is also possible that this support might contain a higher acid strength that enhances the coke formation. XRD results indicated the presence of crystalline $\mathrm{MoO}_{3}$, and bulk or crystalline $\mathrm{MoO}_{3}$ was found to have poor hydrotreating activities. The acidity of silica-supported NiMo catalyst showed increased activity in cumene cracking. Additionally, NiMo/MCM-41 catalyst showed a low thiophene HDS conversion [42]. This was attributed to the small amount of hydroxyl groups on the catalytic surface and due to the generation of three-dimensional Mo species at loading above $10 \mathrm{wt} . \%$ in silica-supported catalysts.

On the contrary, an activated carbon-supported catalyst (NiMo/AC) exhibits higher conversions compared to the silica-supported catalyst, but lower conversions than that of alumina-supported catalyst. The reason for the low activity of the $\mathrm{NiMo} / \mathrm{AC}$ compared to the $\mathrm{NiMo} / \mathrm{Al}_{2} \mathrm{O}_{3}$ catalyst can be explained in two ways. In TEM images, the presence of $\mathrm{MoS}_{2}$ fringes is not clear, meaning that the presence of active metals in this catalyst is very low. Even our XRD results provide evidence that the $\mathrm{MoO}_{3}$ might be present as bulk or crystalline $\mathrm{MoO}_{3}$, which is not as active as the dispersed $\mathrm{MoO}_{3}$. Secondly, an average pore diameter and the total pore volume of this catalyst are also lower compared to the alumina-supported catalyst. Since the $\mathrm{NiMo} / \mathrm{Al}_{2} \mathrm{O}_{3}$ catalyst has a wide pore diameter with an appropriate surface area, the maximum residue hydrotreating and hydrocracking activities are obtained with this catalyst. Additionally, the $\mathrm{NiMo} / \mathrm{Al}_{2} \mathrm{O}_{3}$ catalyst exhibits better dispersion of active metals, which helps to create more brim (active) sites, and thus, more hydrogenation functionality.

\section{Conclusions}

Hydrotreating catalysts were prepared with silica, activated carbon, and mesoporous alumina supports and tested for vacuum residue hydrotreating reactions at $410{ }^{\circ} \mathrm{C}$ temperature and $10 \mathrm{MPa}$ pressure. A comparative performance revealed that, although the silica-supported catalyst possessed a very high surface area, because of its lower pore diameter, it is highly prone to coke formation during residue upgrading processes. This in turn leads to poor conversions and a low yield of liquid products. An activated carbon-supported catalyst (NiMo/AC) exhibits higher conversions compared to the silica-supported catalyst but shows lower activity than the alumina-supported catalyst. One reason is that $\mathrm{NiMo} / \mathrm{AC}$ has a higher pore size distribution than NiMo/SBA15 but a lower distribution than the $\mathrm{NiMo} / \mathrm{Al}_{2} \mathrm{O}_{3}$ catalyst. Another reason is, due to the weak metal-support interaction, less dispersed active phases may present, showing less hydrotreating activity. The $\mathrm{NiMo} / \mathrm{Al}_{2} \mathrm{O}_{3}$ catalyst shows higher asphaltene and residue conversions with lower coke formation. The effectiveness of the $\mathrm{NiMo} / \mathrm{Al}_{2} \mathrm{O}_{3}$ catalyst can be attributed to its larger pore diameter, high pore volume, and better dispersion of active metals. These are favorable properties for residue hydrotreating catalysts.

Author Contributions: K.K.: Methodology, Investigations, Formal Analysis, Writing-Original Draft Preparation, Reviewing and Editing, Visualization. R.P.: Investigations, Reviewing, and Editing. S.K.M.: Supervision, Conceptualization, Reviewing and Editing, Project Administration. B.K.S.: Reviewing and Editing. All authors have read and agreed to the published version of the manuscript. 
Funding: This research received no external funding.

Acknowledgments: K. Kohli gratefully acknowledges the Department of Science and Technology (DST) for fellowship and the CSIR-Indian Institute of Petroleum (CSIR-IIP) for the technical and scientific support.

Conflicts of Interest: The authors declare no conflict of interest.

\section{References}

1. Speight, J.G. The Chemistry and Technology of Petroleum, 3rd ed.; CRC press: New York, NY, USA, 1999.

2. Stratiev, D.; Petkov, K. Residue upgrading: Challenges and perspectives. Hydrocarb. Process 2009, 88, 93-96.

3. Verstraete, J.J.; Le Lannic, K.; Guibard, I. Modeling fixed-bed residue hydrotreating processes. Chem. Eng. Sci. 2007, 62, 5402-5408. [CrossRef]

4. Furimsky, E. Selection of catalysts and reactors for hydroprocessing. Appl. Catal. A Gen. 1998, 171, 177-206. [CrossRef]

5. Rana, M.S.; Ancheyta, J.; Maity, S.K.; Rayo, P. Hydrotreating of Maya crude oil: I. Effect of support composition and its pore-diameter on asphaltene conversion. Pet. Sci. Technol. 2007, 25, 187-199. [CrossRef]

6. Marques, J.; Guillaume, D.; Merdrignac, I.; Espinat, D.; Brunet, S. Effect of catalysts acidity on residues hydrotreatment. Appl. Catal. B Environ. 2011, 101, 727-737. [CrossRef]

7. Rana, M.S.; Srinivas, B.N.; Maity, S.K.; Dhar, G.M.; Rao, T.S.R. Catalytic functionalities of $\mathrm{TiO}_{2}$ based $\mathrm{SiO}_{2}$, $\mathrm{Al}_{2} \mathrm{O}_{3}, \mathrm{ZrO}_{2}$ mixed oxide hydroprocessing catalysts. Stud. Surf. Sci. Catal. 1999, 127, 397-400.

8. Rana, M.S.; Maity, S.K.; Ancheyta, J.; Dhar, G.M.; Rao, T.S.R. $\mathrm{TiO}_{2}-\mathrm{SiO}_{2}$ supported hydrotreating catalysts: Physico-chemical characterization and activities. Appl. Catal. A Gen. 2003, 253, 165-176. [CrossRef]

9. Rana, M.S.; Ancheyta, J.; Maity, S.K.; Rayo, P. Heavy crude oil hydroprocessing: A zeolite based CoMo catalyst and its spent catalyst characterization. Catal. Today 2008, 130, 411-420. [CrossRef]

10. Marafi, M.; Stanislaus, A. Influence of catalyst acidity and feedstock quality on hydrotreating catalyst deactivation by coke deposition. Pet. Sci. Technol. 2001, 19, 697-710. [CrossRef]

11. Maity, S.K.; Flores, L.; Ancheyta, J.; Fukuyama, H. Carbon-modified alumina and alumina-carbon supported hydrotreating catalysts. Ind. Eng. Chem. Res. 2009, 48, 1190-1195. [CrossRef]

12. AlSairafi, S.H.; AlNajdi, N.; AlSheeha, H.; Rana, M.S. Synthesis of alumina support and effect of its properties on thiophene hydrodesulfurization. React. Kinet. Mech. Catal. 2020, 129, 297-313. [CrossRef]

13. Kaluza, L.; Gulkova, D.; Solcova, O.; Zilkova, N.; Cejka, J. Hydrotreating catalysts supported on organized mesoporous alumina: Optimization of Mo deposition and promotional effects of Co and Ni. Appl. Catal. A Gen. 2008, 351, 93-101. [CrossRef]

14. Farag, H.; Whitehurst, D.D.; Sakanishi, K.; Mochida, I. Carbon versus alumina as a support for Co-Mo catalysts reactivity towards HDS of dibenzothiophenes and diesel fuel. Catal. Today 1999, 50, 9. [CrossRef]

15. Farag, H.; Mochida, I.; Sakanishi, K. Fundamental comparison studies on hydrodesulfurization of dibenzothiophenes over CoMo-based carbon and alumina catalysts. Appl. Catal. 2000, 194-195, 147. [CrossRef]

16. Duchet, J.C.; van Oers, E.M.; de Beer, V.H.J.; Prins, R. Carbon supported sulfide catalysts. J. Catal. 1983, 80, 386-402. [CrossRef]

17. Brito, J.L.; Severino, F.; Delgado, N.N.; Laine, J. HDS activity of carbon-supported Ni-Mo catalysts derived from thiomolybdate complexes. Appl. Catal. A Gen. 1998, 173, 193-199. [CrossRef]

18. Kaluza, L.; Zdrazil, M. Carbon-supported Mo catalysts prepared by a new impregnation method using a $\mathrm{MoO}_{3}$ /water slurry: Saturated loading, hydrodesulfurization activity and promotion by Co. Carbon 2001, 39, 2023-2034. [CrossRef]

19. Abotsi, G.M.K.; Scaroni, A.W. A review of carbon supported hydrodesulfurization catalysts. Fuel Process. Technol. 1989, 22, 107-133. [CrossRef]

20. Valencia, D.; Klimova, T.E. Kinetic study of NiMo/SBA-15 catalysts prepared with citric acid in hydrodesulfurization of dibenzothiophene. Catal. Commun. 2012, 21, 77-81. [CrossRef]

21. Valencia, D.; Klimova, T.E. Citric acid loading for $\mathrm{MoS}_{2}$-based catalysts supported on SBA-15. New catalytic materials with high hydrogenolysis ability in hydrodesulfurization. Appl. Catal. B Environ. 2013, 129, 137-145. [CrossRef]

22. Calderon-Magdaleno, M.A.; Mendoza-Nieto, J.A.; Klimova, T.E. Effect of the amount of citric acid used in the pretreatment of NiMo/SBA-15 catalysts on their performance in HDS of dibenzothiophene-type compounds. Catal. Today 2014, 220-222, 78-88. [CrossRef] 
23. Mendoza-Nieto, J.A.; Vera-Vallejo, O.; Escobar-Alarcon, L.; Solis-Casados, D.; Klimova, T. Development of new trimetallic NiMoW catalysts supported on SBA-15 for deep hydrodesulfurization. Fuel 2013, 110, 268-277. [CrossRef]

24. Boahene, P.E.; Soni, K.K.; Dalai, A.K.; Adjaye, J. Application of different pore diameter SBA-15 supports for heavy gas oil hydrotreatment using FeW catalyst. Appl. Catal. A Gen. 2011, 402, 31-40. [CrossRef]

25. Zhao, D.; Huo, Q.; Feng, J.; Chmelka, B.; Stucky, G. Non-ionic triblock and star diblock opolymer and oligomeric surfactant synthesis of highly ordered hydrothermally stable mesoporous silica structure. J. Am. Chem. Soc. 1998, 120, 6024-6036. [CrossRef]

26. Wang, G.; Zhang, L.; Deng, J.; Dai, H.; He, H.; Au, C.T. Preparation, characterization, and catalytic activity of chromia supported on SBA-15 for the oxidative dehydrogenation of isobutene. Appl. Catal. A Gen. 2009, 355, 192-201. [CrossRef]

27. Zuo, D.; Vrinat, M.; Nie, H.; Mauge, F.; Shi, Y.; Lacroix, M.; Li, D. The formation of the active phases in sulfided $\mathrm{NiW} / \mathrm{Al}_{2} \mathrm{O}_{3}$ catalysts and their evolution during post-reduction treatment. Catal. Today 2004, 93-95, 751-760. [CrossRef]

28. Kohli, K.; Prajapati, R.; Maity, S.K.; Sau, M.; Sharma, B.K. Accelerated pre-coking of NiMo/ $\mathrm{Al}_{2} \mathrm{O}_{3}$ catalyst: Effect on the hydroprocessing activity of vacuum residue. Fuel 2019, 235, 437-447. [CrossRef]

29. Kohli, K.; Prajapati, R.; Maity, S.K.; Sau, M.; Garg, M.O. Deactivation of hydrotreating catalyst by metals in resin and asphaltene parts of heavy oil and residues. Fuel 2016, 175, 264-273. [CrossRef]

30. Prajapati, R.; Kohli, K.; Maity, S.K.; Garg, M.O. Coking propensity during hydroprocessing of vacuum residues, deasphalted oils, and asphaltenes. Fuel 2017, 203, 514-521. [CrossRef]

31. Nadjar, W.E.; Bonne, M.; Emmanuelle, T.; Rouleau, L.; Mino, A.; Hocine, S.; Payen, E.; Lancelot, C.; Lamonier, C.; Blanchard, P.; et al. Infrared investigation on surface properties of alumina obtained using recent templating routes. Microporous Mesoporous Mater. 2012, 158, 88-98. [CrossRef]

32. Thommes, M.; Kaneko, K.; Neimark, A.V.; Olivier, P.; Reinoso, F.P.; Rouquerol, J.; Sing, K.S.W. Physisorption of gases, with special reference to the evaluation of surface area and pore size distribution (IUPAC Technical Report). Pure Appl. Chem. 2015, 87, 1051-1069. [CrossRef]

33. Behnejad, B.; Abdouss, M.; Tavasoli, A. Comparison of performance of NiMo/alumina catalyst in HDS and HDN reactions of main distillate fractions. Pet. Sci. 2018, 16, 645-656. [CrossRef]

34. Liu, F.; Xu, S.; Chi, Y.; Xue, D. A novel alumina-activated carbon composite supported NiMo catalyst for hydrodesulfurization of dibenzothiophene. Catal. Commun. 2011, 12, 521-524. [CrossRef]

35. Topsøe, T. The role of Co-Mo-S type structures in hydrotreating catalysts. Appl. Catal. A Gen. 2007, 322, 3-8. [CrossRef]

36. Song, C. An overview of new approaches to deep desulfurization for ultra-clean gasoline, diesel fuel and jet fuel. Catal. Today 2003, 86, 211-263. [CrossRef]

37. Song, C.; Hanaoka, K.; Nomura, M. Influence of pore structure and chemical properties of supported molybdenum catalysts on their performance in upgrading heavy coal liquids. Energy Fuels 1992, 6, 619-628. [CrossRef]

38. Rana, M.S.; Ancheyta, J.; Rayo, P.; Maity, S.K. Heavy oil hydroprocessing over supported NiMo sulfide catalyst: An inhibition effect by added $\mathrm{H}_{2} \mathrm{~S}$. Fuel 2007, 86, 1263-1269. [CrossRef]

39. Puron, H.; Pinilla, J.L.; Berrueco, C.; Montoya De La Fuente, J.A.; Millan, M. Hydrocracking of Maya vacuum residue with NiMo catalysts supported on mesoporous alumina and silica-alumina. Energy Fuels 2013, 27, 3952-3960. [CrossRef]

40. Gray, R.M. Upgrading Petroleum Residues and Heavy Oils; CRC press: New York, NY, USA, 1994; Volume 56.

41. Begon, V.; Warrington, S.B.; Megaritis, A.; Charsley, E.L.; Kandiyoti, R. Composition of carbonaceous deposits and catalyst deactivation in the early stages of the hydrocracking of a coal extract. Fuel 1999, $78,681$. [CrossRef]

42. Kaluza, L.; Karban, J.; Gulkova, D. Activity and selectivity of Co(Ni)Mo sulfides supported on $\mathrm{MgO}$, $\mathrm{Al}_{2} \mathrm{O}_{3}, \mathrm{ZrO}_{2}, \mathrm{TiO}_{2}, \mathrm{MCM}-41$ and activated carbon in parallel hydrodeoxygenation of octanoic acid and hydrodesulfurization of 1-benzothiophene. React. Kinet. Mech. Catal. 2019, 127, 887-902. [CrossRef]

(C) 2020 by the authors. Licensee MDPI, Basel, Switzerland. This article is an open access article distributed under the terms and conditions of the Creative Commons Attribution (CC BY) license (http://creativecommons.org/licenses/by/4.0/). 